\title{
Optimization of Process Parameter for Sawdust/Recycled Polyethylene Composites
}

\author{
Clement U. Atuanya1, Chizoba M. Obele ${ }^{2}$ \\ ${ }^{1}$ Department of Metallurgical and Materials Engineering, Nnamdi Azikiwe University, \\ Awka, Nigeria \\ ${ }^{2}$ Department of Polymer and Textile Engineering, Nnamdi Azikiwe University, \\ Awka, Nigeria \\ Email: atueye2003@yahoo.co.uk, angelobele1@yahoo.co.uk
}

Received 17 April 2016; accepted 26 July 2016; published 29 July 2016

Copyright $@ 2016$ by authors and Scientific Research Publishing Inc.

This work is licensed under the Creative Commons Attribution International License (CC BY).

http://creativecommons.org/licenses/by/4.0/

c) (7) Open Access

\begin{abstract}
In this paper, Okhuen wood sawdust and recycled polyethylene (RLDPE) were blended and then hot-pressed to produce sawdust/recycled polyethylene composite board. The optimum processing parameters for preparing the composite such as temperature, pressing time, sawdust/RLDPE content and pressure were investigated and optimized using $L_{9}\left(3^{4}\right)$ Taguchi experimental design orthogonal array. The tensile strength of the various formulations was determined. The results show that those factors made different effects on the tensile strength of the composites. The optimized process conditions obtained are as follows: press time $7 \mathrm{~min}$, press temperature $180^{\circ} \mathrm{C}$, sawdust/RLDPE 60:40\%, press pressure $40 \mathrm{~kg} / \mathrm{cm}^{2}$. The average tensile strength of the optimized composite board was 13.991 MPa. The composite board met the standard for general purpose applications.
\end{abstract}

\section{Keywords}

Okhuen Wood, Recycled Low Density Polyethylene, Taguchi Method, Tensile Properties

\section{Introduction}

Particleboard is a panel product manufactured under pressure from particles of wood or other lignocellulosic materials and an adhesive. Particleboard has been widely used throughout the world for furniture manufacture and house construction, including flooring systems, etc. [1]. Recently, the demand for the particleboard has continued to increase for housing construction and furniture manufacturing [2].

According to the end use of wood-wastes and their possible reuse products, particleboard found typical appli- 
cations as flooring, wall and ceiling panels, office dividers, bulletin boards, furniture, cabinets, counter tops, and deck tops [2], and it seems that the manufacture of particleboard from recycled wood-based wastes is the most common way to reuse such waste materials [3] [4]. An extensive review on the hot-compression of plywood and particleboard was published by Bolton and Humphrey [4]. The primary physical processes and their interactions were identified. A need for the development of a comprehensive hot-compression model was recognized.

Nemli et al. [5] have investigated the effects of various parameters on the surface roughness of particleboard. According to their study, density is one of the major factors influencing the surface roughness of particleboard. Tabarsa et al. [6] have concluded that increasing press time and moisture content of the particleboard decreases the surface roughness. Prakash et al. [7] have formulated a mathematical model for the prediction of surface roughness in drilling Medium Density Fiberboard (MDF) panel. Their results showed that the surface roughness increased with decreased spindle speed and increased feed rate.

Talavera et al. [8] studied the effect of production variables on bending properties, water absorption and thickness swelling of bagasse/plastic composite boards. They concluded that Modulus of Rupture (MOR) and bending modulus of elasticity (MOE) increased proportionally with press temperature and press time. An increase of the bagasse content was found to have a positive effect only on the bending MOE and increase in pressure had a negative effect on both bending strength and MOE. Water absorption and thickness swelling were reduced significantly by an increase in temperature and pressing time, whereas variation of pressure did not have any influence on these board properties.

There are several designs that are in use in design of experiments such as incomplete block designs, Youden square designs, lattice square designs, Taguchi designs, fractional factorial designs, Graeco-Latin square designs, split-plot designs, covariance design or time-series, factorial designs, Plackett-Burman design, etc. According to Ben-Gal (2005) [9], among the several experimental design methods, Taguchi method has made valuable contributions to statistics and engineering. Genichi Taguchi emphasis is on loss to society techniques for investigating variation in experiments, and his overall strategy of system parameter and tolerance design have been influential in improving manufactured quality products worldwide. It reduces testing cycle time and analysis is simple. Although some of the statistical aspects of the Taguchi methods are disputable, there is no dispute that they are widely applied to various processes. A quick search at World Wide Web reveals that the method is being successfully implemented in diverse areas, such as optimization of communication and information network, development of electronic circuits, laser engineering of photo masks, cash-flow optimization in banking, policy making, runway utilization improvement in airports and even robust eco-design. The approach provides more complete interaction information than typical fractional factorial design (Ben Gal et al. 2008) [10].

The Taguchi method helps to ease the process of analyzing the experimental results and get insight into the phenomenon of experimentation. The goal of the Taguchi method is to reduce costs to the manufacture and the society from variability in manufacturing processes. The overall objective is to produce high quality product at low cost to the manufacturer.

In this work, the Taguchi method is employed to achieve this aim. Here L9 orthogonal array with four factors and three levels was employed to optimize the process parameters (temp, time, pressure and mix content). The performance characteristics for the larger the better situations were evaluated for maximization properties of tensile strength.

Despite the availability of these studies, no investigation has been conducted on the optimization of the processing process of Okhuen wood sawdust/polyethylene composite boards. A relationship between the tensile property of the composite board and process parameters is desirable to obtain the better understanding on the tensile strength. Based on the above-mentioned situation, the study described in this work intends to: investigate optimization of the processing parameters on the tensile strength of Okhuen wood sawdust/RLDPE composite board.

Provided throughout this document and are identified in italic type, within parentheses, following the example. Some components, such as multi-leveled equations, graphics, and tables are not prescribed, although the various table text styles are provided. The formatter will need to create these components, incorporating the applicable criteria that follow.

\section{Material and Method}

\subsection{Materials}

The sawdust of Okhuen wood (Brachistegia nigerica) used in this work was obtained directly from a sawmill factory in Benin, Nigeria. Waste polyethylene bags (empty water sachets) of the same kind and type were col- 
lected from Nnamdi Azikwe University premises, Awka, Nigeria. They were pulverized, washed with clean water and dried.

\subsection{Equipment}

Equipment used in this research were: digital weighing machine, drying oven, veneer calliper, set of sieves, hydraulic press machine model No PUJI200E and Hounsfield Tensometer and two roll mill etc.

\subsection{Method}

The particle size analysis of the sawdust particles was carried out in accordance with BS EN 933-2 1996 [11]. $100 \mathrm{~g}$ of sawdust particles was placed unto a set of sieves arranged in descending order of fineness and shaken for 15 min which is the recommended time to achieve complete classification; the particles that were retained in the BS $420 \mu \mathrm{m}$ was used in this study.

In this work, manufacturing parameters with four factors (A, B, C, D) and three levels $(1,2,3)$ were selected to build a proper Taguchi orthogonal array (Table 1).

In this work all the selected manufacturing parameters are control factors; outer array for noise factors was not considered.

Table 2 shows the different process factors and their level combinations with responses (tensile strength). The experiments were conducted against the conditions shown in Table 2. The performance characteristics for the "larger the better" situations were evaluated for maximizing tensile strength of the product.

\subsection{Experiment}

The sawdust was oven dried to a moisture content of less than $6 \%$ and waste polyethylene bags (water sachets) particulate were weighed for each formulation (Table 2). The mixture was then compounded in a two roll mill model No. 5183 supplied by reliable rubber and plastic machinery company U.S.A at College of Chemical and leather technology (CHEL TECH) Zaria, Nigeria. The temperature of the two roll mill was set at $130^{\circ} \mathrm{C}$ during mixing process.

Table 1. Manufacturing parameters and their levels.

\begin{tabular}{ccccc}
\hline Manufacturing parameter designation & Manufacturing parameter & Level 1 & Level 2 & Level 3 \\
\hline A & Press temperature $\left({ }^{\circ} \mathrm{C}\right)$ & 140 & 160 & 180 \\
B & Press time (min) & 7 & 10 & 13 \\
C & Sawdust/plastic content $(\%)$ & $40 / 60$ & $50 / 50$ & $60 / 40$ \\
D & Press pressure $\left(\mathrm{kg} / \mathrm{cm}^{2}\right)$ & 30 & 40 & 50 \\
\hline
\end{tabular}

Table 2. Various factor levels and manufacturing parameters for sawdust/polyethylene formulations.

\begin{tabular}{|c|c|c|c|c|c|c|c|c|}
\hline $\begin{array}{l}\text { Exp. } \\
\text { No. }\end{array}$ & $\begin{array}{l}\text { Randomized } \\
\text { run order }\end{array}$ & $\begin{array}{l}\text { Temp. } \\
\mathrm{A}\left({ }^{\circ} \mathrm{C}\right)\end{array}$ & $\begin{array}{c}\text { Time } \\
\text { B (min) }\end{array}$ & $\begin{array}{c}\text { Sawdust/plastic } \\
\text { content C \% }\end{array}$ & $\begin{array}{l}\text { Pressure } \\
\mathrm{D} \mathrm{kg} / \mathrm{cm}^{2}\end{array}$ & $\begin{array}{c}\text { Tensile } \\
\text { strength } \mathrm{MPa} \mathrm{R}_{1}\end{array}$ & $\begin{array}{c}\text { Tensile } \\
\text { strength } \mathrm{MPa} \mathrm{R}_{2}\end{array}$ & $\begin{array}{c}\text { Tensile } \\
\text { strength } \mathrm{MPa} \mathrm{R}_{3}\end{array}$ \\
\hline 1 & 3 & 140 & 7 & $40 / 60$ & 30 & & & \\
\hline 2 & 7 & 140 & 10 & $50 / 50$ & 40 & & & \\
\hline 3 & 5 & 140 & 13 & $60 / 40$ & 50 & & & \\
\hline 4 & 1 & 160 & 7 & $50 / 50$ & 50 & & & \\
\hline 5 & 4 & 160 & 10 & $60 / 40$ & 30 & & & \\
\hline 6 & 6 & 160 & 13 & $40 / 60$ & 40 & & & \\
\hline 7 & 9 & 180 & 7 & $60 / 40$ & 40 & & & \\
\hline 8 & 2 & 180 & 10 & $40 / 60$ & 50 & & & \\
\hline 9 & 8 & 180 & 13 & $50 / 50$ & 30 & & & \\
\hline
\end{tabular}


After compounding of sawdust/waste polyethylene sachet particulates, the compounded materials were placed in turn into the fabricated mould. The inside surface of the mould was coated with silicon oil to avoid adhesion of the mixture and to allow easy removal of the composite sample from the mould. Compression molding of the mixture was done using 40 tons electrical heated hydraulic press supplied by Moore Birmingham U.K, serial No.D288. The composites were produced in accordance with $\mathrm{L}_{9}\left(3^{4}\right)$ Taguchi method (Table 2). At the end of each press cycle, the samples were removed from the mould after cooling at room temperature. Prior to tensile strength test the samples were conditioned at constant room temperature and $65 \%$ relative humidity (RH) in accordance to ASTM D 618.

Tensile strength measurement of the samples was determined using Hounsfield Tensometer W3179. The cross head speed during the test-was $3 \mathrm{~mm} / \mathrm{min}$. Nine (9) specimens from each sample were tested. The specimen was loaded using self-aligning, self tightening grip that distributes the force evenly over the grip surface and did not allow slipping. The load was applied continuously throughout the test at a uniform rate of motion of the moveable crosshead of the testing machine. The maximum tensile stress was calculated in accordance with Equation (1).

$$
R_{T}=\frac{P_{\max }}{b d}
$$

where $b$ = width of reduced cross-section of the specimen measured in dry condition in mm $d=$ thickness of the specimen measured in dry condition, $P_{\max }=$ maximum tensile load $(\mathrm{N}), R_{t}=$ maximum tensile stress $(\mathrm{MPa})$.

The raw data were converted to signal-to noise $(\mathrm{S} / \mathrm{N})$ ratio $(\mathrm{dB})$. This transformation consolidates the repeated responses (raw data) in each trial condition into a single number. The $\mathrm{S} / \mathrm{N}$ ratios were calculated which in turn also reduced the total degree of freedom (DOF) of the experiments [12]. The quality characteristics for tensile strength after fracture is higher the better type so the signal-to-noise ratio ( $\mathrm{S} / \mathrm{N}$ ration) for the higher the better type was used and is given in Equation (2)

$$
\left(\frac{S}{N}\right)_{H B}=-10 \log \left[\frac{1}{n} \sum_{j=1}^{R}\left(\frac{1}{x_{j}^{2}}\right)\right]
$$

where $x_{j}, j=1,2, \cdots, n$ the response values for the trial conditions repeated "n" times.

\section{Results and Discussion}

\subsection{Tensile Test Results}

Table 3 shows the values of tensile strength (responsses) obtained from experiments conducted in line with Table 2. Since three trials for each experiment were conducted, three responses were obtained as in Table 3 . To achieve robustness the signal- to noise $(\mathrm{S} / \mathrm{N})$ ratio for each experiment was computed for tensile strength after fracture for each of the nine trial values. The values $(\mathrm{S} / \mathrm{N}$ ratio) are also presented in Table 3.

\begin{tabular}{|c|c|c|c|c|c|c|c|c|c|c|}
\hline $\begin{array}{l}\text { Exp. } \\
\text { No. }\end{array}$ & $\begin{array}{l}\text { Randomized } \\
\text { run order }\end{array}$ & $\begin{array}{r}\text { Temp } \\
\text { A }\left({ }^{\circ} \mathbf{C}\right)\end{array}$ & $\begin{array}{c}\text { Time } \\
\text { B (min) }\end{array}$ & $\begin{array}{l}\text { Sawdust/plastic } \\
\text { content C (wt\%) }\end{array}$ & $\begin{array}{l}\text { Pressure } \\
\text { D kg/ } \mathrm{cm}^{2}\end{array}$ & $\begin{array}{c}\mathbf{R}_{1} \\
\mathrm{MPa}\end{array}$ & $\mathbf{R}_{2} \mathbf{M P a}$ & $\mathbf{R}_{3} \mathbf{M P a}$ & $\begin{array}{l}\text { Rav } \\
\text { MPa }\end{array}$ & $\begin{array}{c}\mathrm{S} / \mathrm{N} \\
\text { ratio }(\mathbf{d b})\end{array}$ \\
\hline 1 & 3 & 140 & 7 & $40 / 60$ & 30 & 8.53 & 8.53 & 7.25 & 8.10 & 18.095 \\
\hline 2 & 7 & 140 & 10 & $50 / 50$ & 40 & 12.38 & 9.41 & 12.38 & 11.39 & 20.907 \\
\hline 3 & 5 & 140 & 13 & $60 / 40$ & 50 & 7.2 & 8.03 & 8.11 & 7.78 & 17.781 \\
\hline 4 & 1 & 160 & 7 & $50 / 50$ & 50 & 13.83 & 12.38 & 11.28 & 12.50 & 21.845 \\
\hline 5 & 4 & 160 & 10 & $60 / 40$ & 30 & 11.28 & 12.59 & 14.58 & 12.81 & 22.012 \\
\hline 6 & 6 & 160 & 13 & $40 / 60$ & 40 & 11.81 & 10.18 & 12.38 & 11.46 & 21.089 \\
\hline 7 & 9 & 180 & 7 & $60 / 40$ & 40 & 15.64 & 14.58 & 13.19 & 14.47 & 23.145 \\
\hline 8 & 2 & 180 & 10 & $40 / 60$ & 50 & 7.71 & 8.53 & 10.18 & 8.81 & 18.727 \\
\hline 9 & 8 & 180 & 13 & $50 / 50$ & 30 & 9.82 & 10.67 & 9.24 & 9.91 & 19.876 \\
\hline
\end{tabular}

Table 3. Various factors and their levels with obtained tensile strength and $\mathrm{S} / \mathrm{N}$ ratio of different composites produced. 


\section{Over all mean $\dot{\mathbf{T}} \mathbf{= 1 0 . 8 0}$.}

\section{Data Analysis of Tensile Test Results}

Tensile strength result (Table 4) was analyzed using Microsoft Excel software in conjunction with the equations outlined in the method described by Kumar et al (2008) [13]. From the analysis, the average values of the tensile strength after fracture for each parameter (temperature- $\mathrm{A}$, time- $\mathrm{B}$, sawdust/polyethylene content- $\mathrm{C}$, and pressure-D) at levels 1,2 and 3 settings for composites at $425 \mu \mathrm{m}$ were obtained. The main effect of the various process parameters when they change from the lower to higher levels are presented in Table 5 .

From Table 4, it is clear that tensile strength after fracture is highest at level three of parameter $A\left(A_{3}\right)$, level one (L1) of parameter $B\left(B_{1}\right)$, third level of parameter $C\left(C_{3}\right)$ and second level of parameter $D\left(D_{2}\right)$. This suggests that these levels of process parameters are the best levels for maximum tensile strength. The findings are outlined in Table 5 and also shown in Figures 1(a)-(d).

It is clear from Figure 1(a) that tensile strength increases with increase in press temperature of the board from $9.09 \mathrm{MPa}\left(140^{\circ} \mathrm{C}\right)$ and continued up to $12.26 \mathrm{MPa}$ at temperature of $180^{\circ} \mathrm{C}$. This increase may be due to the fact that temperature of $180^{\circ} \mathrm{C}$ is enough for the RLDPE binder to completely melt and flow evenly filling the pores of the sawdust particles.

It can be visualized from Figure 1(b), that tensile strength decreases from press time of 7 mins to 13 mins. The 7 mins of heating and holding is enough for RLDPE binder to melt and flow to the core of the mat filling all the pores of the sawdust. Also in Figure 1(c), the tensile strength increases with increasing sawdust loading. This is due to fairly good interfacial bonding between sawdust and the polyethylene binder. The RLDPE binder is enough to completely wet and bind all the sawdust particulates which resulted to rise in tensile strength [1] [2].

From Figure 1(d), is clear that the tensile strength increases with press pressure. This is expected since the particles are compacted more and therefore closely packed. The slight reduction in tensile strength may be due to spring back effect. This is due to the fact that the boards were cooled outside of the press with the temperature still above the plastic melting point. This rather abrupt change in temperature may have caused a post press spring back effect that tore the polymer melt and reduce bond between sawdust particles and plastic. This effect is expected to become more pronounced with higher pressure [7].

Table 4. Main effect on tensile strength (raw data) for 425 m sawdust/print on RLDPE.

\begin{tabular}{|c|c|c|c|c|c|}
\hline Process parameter & Level & Temp (A) & Time (B) & Sawdust/polyethylene content (C) & Pressure (D) \\
\hline \multirow[t]{3}{*}{$\begin{array}{c}\text { Average value } \\
\text { tensile strength (MPa) }\end{array}$} & L1 & 9.091 & 11.69 & 9.455 & 10.276 \\
\hline & L2 & 11.062 & 11.004 & 11.265 & 12.438 \\
\hline & L3 & 12.256 & 9.715 & 11.688 & 9.694 \\
\hline \multirow[t]{2}{*}{$\begin{array}{c}\text { Main effects } \\
\text { (tensile strength) (MPa) }\end{array}$} & L2 - L1 & 3.165 & -0.685 & 1.810 & 2.162 \\
\hline & L3 - L2 & -1.194 & 0.423 & 0.423 & 2.744 \\
\hline Differences & [(L3 - L2)-(L2 - L1)] & -4.360 & -1.386 & -1.386 & -4.906 \\
\hline
\end{tabular}

L1, L2 and L3 represent average values raw data at levels 1,2 and 3, respectively, of parameters. L2 - L1 is the average main effect when the corresponding parameter changes from level 1 to level 2. L3 - L2 is the average main effect when the corresponding parameter changes from level 2 to level 3 .

Table 5. Optimum levels of process parameters (tensile strength) for polyethylene/sawdust $425 \mu \mathrm{m}$ particle size composite.

\begin{tabular}{ccc}
\hline Process parameter & Parameter designation & Optimal level for maximum tensile strength \\
Temperature $\left({ }^{\circ} \mathrm{C}\right)$ & $\mathrm{A}_{3}$ & 180 \\
Time $(\mathrm{min})$ & $\mathrm{B}_{1}$ & 7 \\
Sawdust/polyethylene content $(\mathrm{wt} \%)$ & $\mathrm{C}_{3}$ & $60 / 40$ \\
Pressure $\left(\mathrm{kg} / \mathrm{cm}^{2}\right)$ & $\mathrm{D}_{2}$ & 40 \\
\hline
\end{tabular}




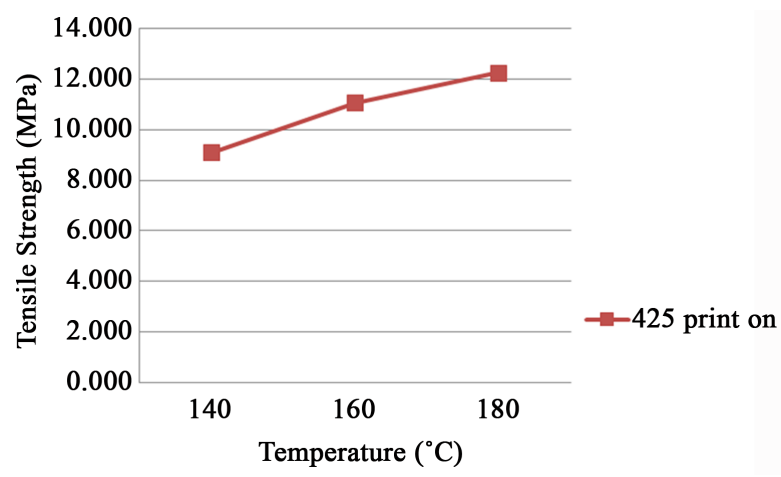

(a)

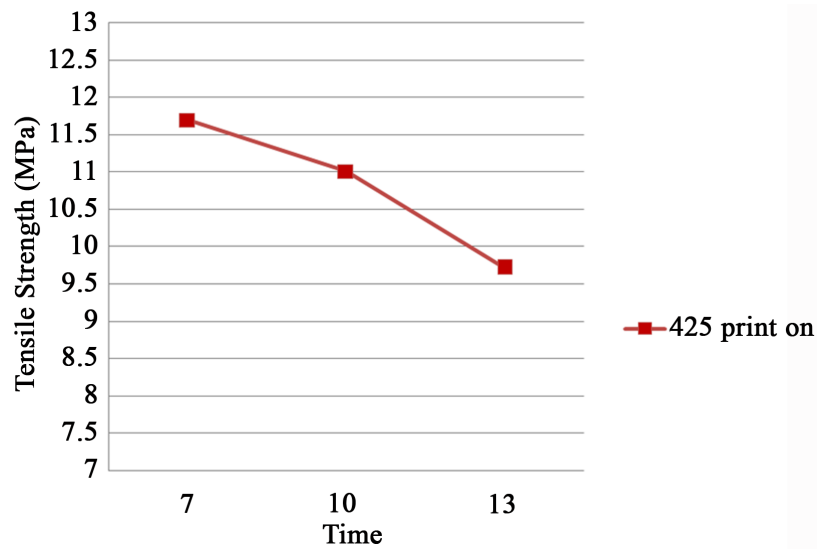

(b)

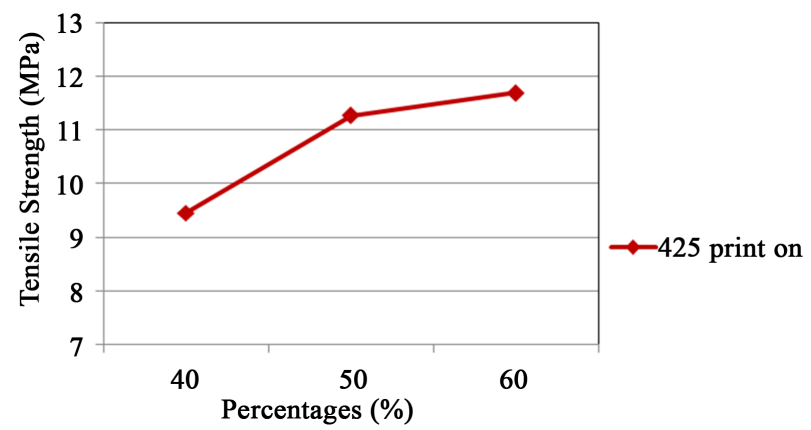

(c)

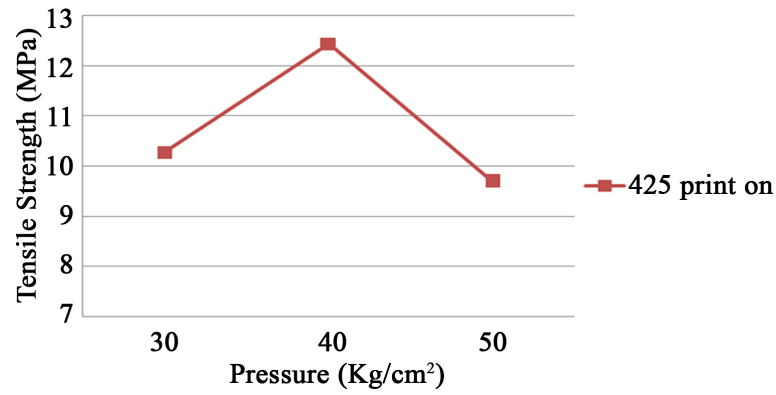

(d)

Figure 1. (a) The effect of temperature on composite strength (tensile strength); (b) The effect of time on composite strength (tensile strength); (c) The effect of sawdust/poly content on composite tensile strength; (d) The effect of pressure on composite strength (tensile strength). 


\subsection{Signal to Noise (S/N) Ratio}

As an evaluation tool for determining robustness, the signal-to-noise $(\mathrm{S} / \mathrm{N})$ ratio is the most important component of a parameter design in Taguchi method, the term "signal" represents the desirable target for good products and the term "noise" represents the undesirable value.

The optimum conditions were also determined from the $\mathrm{S} / \mathrm{N}$ ratios shown in Table 3. Using those values of $\mathrm{S} / \mathrm{N}$ ratios in Table 3, the average values of $\mathrm{S} / \mathrm{N}$ ratios of various process parameters at different levels were calculated. The values obtained are presented in Table 6.

From Table 6, it is clear that levels 3, 1, 3 and 2 of process parameters A, B, C, and D respectively are the best levels for maximum tensile strength (S/N Ratio). This is in agreement with that in Table 5.

In order to study the significance of the process parameters towards the tensile strength after fracture, analysis of variance (ANOVA) was performed. Table 7 shows the result of analysis of variance (ANOVA) for tensile strength after fracture for $425 \mu \mathrm{m}$ composite. The ANOVA indicates the relative significance of the manufacturing parameter affecting the quality characteristics (tensile strength) and shows the contribution of each ingredient to finding out their importance towards achievement of the target performance. The ANOVA table suggests that tensile strength of the composite was strongly affected by press temperature and press pressure. The suggestion is based on the percentage contribution of the manufacturing parameters as shown in Table 7 .

ANOVA is also required for determining the error variance for the effects and variance of prediction error. This is to be accomplished by separating the total variability of $\mathrm{S} / \mathrm{N}$ ratio, which is measured by deviations from the total mean $\mathrm{S} / \mathrm{N}$ ratio, into contributions of each of the design parameters and the error [1]-[3].

The \% contribution designates the relative power of a parameter to diminish variation. A parameter with a high \% contribution and a small variation has a huge control on the response. The ANOVA of the raw data for tensile strength of the composites is presented in Table 7. From Table 7, it can be seen that temperature has the highest influence (28.140\% followed by pressure (22.68\%) and then sawdust/poly (14.644\%) on optimization of the tensile strength, whereas time does not have much effect (9.917\%) in optimizing of the tensile strength.

The optimum value of tensile strength was predicted at the selected levels and the estimated mean computed as outline by Kumar et al. [13] and was found to be $13.90 \mathrm{MPa}$.

Three confirmation experiments were conducted at optimum conditions (Table 5) of the process parameters. Some blended sawdust/waste polyethylene formulation of $60 / 40 \mathrm{wt} \%$ were pressed to tensile shape specimens under obtained optimum process parameter conditions of: press temperature $180^{\circ} \mathrm{C}$, press time 7 min, sawdust/polyethylene content 60/40, press pressure $40 \mathrm{~kg} / \mathrm{cm}^{2}$. The average tensile strength obtained was $13.99 \mathrm{MPa}$. This value is within the confidence interval of predicted optimum tensile strength of the composite.

Table 6. Main effect on tensile strength (S/N Ratio) for $425 \mathrm{~mm}$ sawdust polyethylene composites.

\begin{tabular}{|c|c|c|c|c|c|}
\hline Process parameter & Level & Press temp ${ }^{\circ} \mathrm{C}$ & Press time min & Sawdust/polyethylene content (wt\%) & Press pressure $\mathrm{Kg} / \mathrm{cm}^{3}$ \\
\hline \multirow[t]{3}{*}{ Average value (TS) } & L1 & 50 & 63 & 63.1 & 60 \\
\hline & L2 & 61.6 & 61.6 & 66.2 & 65.1 \\
\hline & L3 & 65 & 58.7 & 66.6 & 58.1 \\
\hline
\end{tabular}

Table 7. Anova raw data (tensile strength) for $425 \mu \mathrm{m}$ sawdust/RLDPE.

\begin{tabular}{cccccc}
\hline Source & SS & DOF & V & F & P(\%) \\
Temp & 45.998 & 2.0 & 22.999 & 15.860 & 43.098 \\
Time & 18.088 & 2.0 & 9.044 & 6.237 & 15.188 \\
Sawdust & 25.329 & 2.0 & 12.664 & 8.733 & 22.429 \\
Pressure & 37.638 & 2.0 & 18.819 & 12.978 & 34.738 \\
Error & 26.100 & 18.0 & 1.450 & & 22.681 \\
Total & 153.155 & 26.0 & & 18.935 \\
\hline
\end{tabular}




\section{Conclusions}

Taguchi experimental design method can be used to analyze the tensile strength of the sawdust/recycled polyethylene composites as described in the paper. The following generalized conclusions can be drawn from the work.

1) The formulation for manufacture of Okhuen wood sawdust/low density polyethylene composite was developed through the optimization of process parameters using Taguchi method.

2) Data on tensile properties of Okhuen wood composite have been experimentally determined.

3) The pressing temperature, ratio of sawdust/recycled polyethylene and pressure are the processing factors that have the highest influence on the tensile strength of the materials

4) Effect of the process parameters: pressure and temperatures is more pronounced on the tensile strength of the composite

5) Taguchi design of the experiment can be successfully employed to describe the tensile strength process of the samples and the optimum processing condition obtained are: temperature $180^{\circ} \mathrm{C}$, press time $7 \mathrm{~min}$, sawdust/polyethylene content $60 / 40$, press pressure $40 \mathrm{~kg} / \mathrm{cm}^{2}$ with average tensile strength obtained as 13.90 MPa.

\section{References}

[1] Nemli, G. (2003) Effects of Some Manufacturing Factors on the Properties of Particleboard Manufactured from Alder (Alnus glutinosa subsp. Barbata). Turkish Journal of Agriculture and Forestry, 27, 99-104.

[2] Nemli, G. and Kalaycoglu (2003) Producing Composite Particleboard from Kenaf (Hibiscus cannabinus L.) Stalks. Industrial Crops and Products, 24, 177-180.

[3] Kruse, K., Thomen, H., Maurer, H., Steffena, A. and Leon-Mendez, R. (1997) Optimization of Particleboard Production by Means of Process Modeling. Holz als Roh- und Werkstoff, 55, 17-24. http://dx.doi.org/10.1007/s001070050218

[4] Bolton, A.J., Humphrey, P.E. and. Kavvouras, P.K. (1989) The Hot-Pressing of Dry Formed Wood-Based Composites. Part IV. Predicted Variation of Mattress Moisture Content with Time. Holzforschung, 43, 345-349. http://dx.doi.org/10.1515/hfsg.1989.43.6.406

[5] Nemli, G., Ismail, A. and Zekovic, E. (2007) Evaluation of Some of the Properties of Particle Board as Function of Manufacturing Parameters. Journal of Materials and Design, 28, 1169-1176. http://dx.doi.org/10.1016/j.matdes.2006.01.015

[6] Taghi, T., Alireza, A. and Gholamzadeh, M. (2011) Evaluation of Surface Roughness and Mechanical Properties of Particle Board Panels Made from Bagasse. Composites Part B: Engineering, 42, 1330-1335. http://dx.doi.org/10.1016/j.compositesb.2010.12.018

[7] Prakash, S. and Palani Kumar, K. (2010) Modeling for Prediction of Surface Roughness in Drilling MDF Panels Using Response Surface Methodology. Journal of Composite Materials, 45, 1639-1646. http://dx.doi.org/10.1177/0021998310385026

[8] Fuentes Talavera, F.J., Silva Guzman, J.A., Richter, H.G. and Ramos Quirarte, J. (2007) Effects of Production variables on Bending Properties, Water Absorption and Thickness Swelling of Bagasse/Plastic Composite Boards. Industrial Crops and Products, 26, 1-7. http://dx.doi.org/10.1016/j.indcrop.2006.12.014

[9] Ben, G. (2005) The Use of Data Compression Measures to Assess Robust Designs. IEEE Transactions on Reliability, 54, 381-388. http://dx.doi.org/10.1109/TR.2005.853280

[10] Ben-Gal, I., Katz, R. and Bukchin, Y. (2008) Robust Eco-Design: A New Application for Quality Engineering. IIE Transactions, 40, 907-918.

[11] BS EN 933-2 1996 Test for Geometrical Properties of Aggregates: Determination of Particle Sizes Distribution Test Sieves, Nominal Size Apertures.

[12] Ross, P.L. (1988) Taguchi Techniques for Quality Engineering. McGraw-Hill Book Company, New York.

[13] Kumar, S., Kumar, P. and Shan, H.S. (2008) Optimization of Tensile Properties of Evaporative Pattern Casting Process through Taguchi’s Method. Journal of Materials Processing Technology, 204, 59-69.

http://dx.doi.org/10.1016/j.jmatprotec.2007.10.075 


\section{Submit or recommend next manuscript to SCIRP and we will provide best service for you:}

Accepting pre-submission inquiries through Email, Facebook, LinkedIn, Twitter, etc.

A wide selection of journals (inclusive of 9 subjects, more than 200 journals)

Providing 24-hour high-quality service

User-friendly online submission system

Fair and swift peer-review system

Efficient typesetting and proofreading procedure

Display of the result of downloads and visits, as well as the number of cited articles

Maximum dissemination of your research work

Submit your manuscript at: http://papersubmission.scirp.org/ 